\title{
Modelling of Household Electro-Thermal Technologies for Demand Response Applications
}

Link to publication record in Manchester Research Explorer

\section{Citation for published version (APA):}

Zhang, L., Good, N., Navarro-Espinosa, A., \& Mancarella, P. (2014). Modelling of Household Electro-Thermal Technologies for Demand Response Applications. In IEEE ISGT Europe 2014

\section{Published in:}

IEEE ISGT Europe 2014

\section{Citing this paper}

Please note that where the full-text provided on Manchester Research Explorer is the Author Accepted Manuscript or Proof version this may differ from the final Published version. If citing, it is advised that you check and use the publisher's definitive version.

\section{General rights}

Copyright and moral rights for the publications made accessible in the Research Explorer are retained by the authors and/or other copyright owners and it is a condition of accessing publications that users recognise and abide by the legal requirements associated with these rights.

\section{Takedown policy}

If you believe that this document breaches copyright please refer to the University of Manchester's Takedown Procedures [http://man.ac.uk/04Y6Bo] or contact uml.scholarlycommunications@manchester.ac.uk providing relevant details, so we can investigate your claim.

\section{OPEN ACCESS}




\title{
Modelling of Household Electro-Thermal Technologies for Demand Response Applications
}

\author{
Lingxi Zhang, Student Member, IEEE, Nicholas Good, Student Member, IEEE, Alejandro Navarro- \\ Espinosa, Student Member, IEEE and Pierluigi Mancarella, Senior Member, IEEE
}

\begin{abstract}
With increasing penetration of renewable and low carbon energy resources and electrification of energy consumption, Demand Response (DR) is expected to play a more important role in system balancing, network capacity support, and wholesale electricity markets. However, the side effects of DR control could cause various issues that could eventually hinder its deployment. Therefore the impact of DR needs to be properly understood and modelled. A potentially significant source of DR may be found in control of electro-thermal technologies (ETT, i.e. electric heat pump and micro combined heat and power units) installed in the domestic sector, which could help to alleviate low voltage network congestion. In this respect, this paper introduces a detailed physical model which is used to simulate, with high resolution, the load shapes of different ETT in different buildings with different thermal inertia characteristics. Simulation studies are carried out to evaluate the changes in load patterns in the different cases and the impact of possible DR control strategies, also taking into account the thermal comfort level of occupants. The high resolution model developed aims at giving insights on the expected load pattern changes when applying different DR control schemes to different ETT and in different types of houses.
\end{abstract}

Index Terms-- combined heat and power, electric heat pump, demand response, thermal inertia, thermal storage

\section{INTRODUCTION}

$\mathrm{D}$ ESIRE to mitigate the effects of climate change has made decarbonisation of the energy system an indisputable requirement for all developed countries, the UK being no exception [1]. Decarbonisation of domestic heating, which constitutes $85 \%$ of final energy consumption in the residential sector, is particularly challenging given the dominant role played by gas, which is responsible for $80 \%$ of the heat supply [2]. In future scenarios, decarbonisation may be achieved through increasing penetration of low carbon electro-thermal technologies (ETT), such as electric heat pumps (EHP) and micro-combined heat and power unit (micro-CHP) [3].This will result in a heating sector that is much more tightly coupled with the electricity system than previously.

The transformations mentioned above will have various implications on the way the power system is operated. For example, integration of variable renewable energy sources (RES) (wind and solar, etc.) calls for more reserves to be available in the system [4]. Concurrently, the growth of electrical demand brought by electrification could substantially increase local and system peak consumptions, which would require grid reinforcement at different levels [5].

One of the solutions to these challenges resides in demand response (DR). There are various advantages of DR, such as fast response times and high ramp rates (especially for energy reduction). However the highly distributed and comparatively small nature of the resources may impede widespread DR implementation [6]. In this circumstance, an aggregator can be introduced in order to exploit the benefits of the DR and other distributed resources [7]. Another potential issue of DR is the load pattern variation, as researched in [8], [9], which may result in a demand increase after reduction due to the DR event. In this respect, in [8], [9] several control strategies have been examined to reduce the peak power resulting after DR. So far, however, there has been little discussion about the systematic changes in load patterns that could emerge from implementation of future ETT relative to the gas boilers that are currently used today (at least in the UK). Further, there has been little research on the systematic effect of the choice of DR control strategy, which may significantly alter the resultant load shapes, and for which specific models need to be developed. These effects may be material due to the inherent thermal inertia of the building and heating system components, and thus should be explicitly considered. Several techniques built on bottom-up modelling techniques have been published for the modelling building thermal loads in the residential sector [10], [11]. However none of the models introduced in [10], [11] has simultaneously included the key characteristics of high granularity (requisite for studies on electricity network impact and system balancing applications), multi-energy focus (necessary for systematic studies on interactions between energy vectors), and physical basis (essential for the proper understanding of the building's thermal inertia, amongst others, and of the interplay between different heating system components subject to a given control strategy).

This paper thus introduces a model that aims at creating a deeper understanding of the above features with respect to ETT based heating system modelling for provision of DR. In this model, the individual components of the dwelling's heating system are specifically modelled. Generic configurations of the heating system, ETT and heat emitters are also recognised and modelled. One of the main contributions of this model is the capability of generating a comprehensive set of multi-energy (gas and electricity) consumption profiles by combining the energy consumptions of heating units and non-thermal related load. Additionally, the model can be used to assess the effects of DR applications, including the impact of the selected control strategies. Specific case studies examine the load shape changes of relatively 
high/low thermal demand houses under time-constrained DR controls. Different combinations of heating units (air source heat pump (ASHP) backed up by electric boiler and microCHP unit backed up by gas boiler) and heat emitters (radiator and underfloor heating) are considered. Moreover, taking into account the comfort level of occupants, the impact of alternative indoor temperature controls on the performance and impact of the DR is discussed.

\section{MODEL DESCRIPTION}

The domestic energy consumption model presented in this paper can be subdivided into several parts: electrical appliances, domestic hot water (DHW), heating units, heat distribution system and space heating.

\section{A. Electrical appliances model}

The electrical appliances model is adapted from a version of the tool developed in [12]. This tool can generate profiles of the occupants' activities, the energy consumption of electrical appliances and the lighting demand, based on probabilistic mechanisms. The electrical appliances for space heating purpose have been excluded from this model as the space heating demand is being separately evaluated in our model.

\section{B. DHW model}

The DHW model is established by using information on the occupants' activities (such as bathing) and the operation of electrical appliances (such as dishwashers, washing machines), adapted from [12], with specific DHW consumption rates to generate the DHW demand profile. The detail of the validation process of the DHW model is introduced in [13]. The thermal demand of DHW provision $\left(H_{D H W}\right)$ can be measured according to the operating state of appliances $\left(u_{i, t}\right)$, corresponding DHW consumption rate $\left(m_{i, t}\right)$, the delivery temperature $\left(T_{\text {delivery }}\right)$, intake temperature ( $\left.T_{\text {intake }}\right)$, and the specific heat capacity of water $\left(c_{p}^{\text {water }}\right)$, as described in (1).

$$
H_{D H W}=\sum_{i=1}^{I}\left[\left(T_{\text {delivery }}-T_{\text {intake }}\right) c_{p}^{\text {water }} u_{i, t} m_{i, t}\right]
$$

\section{Heating unit modelling}

For the purpose the studies considered here, the model includes three different primary heating unit choices. The characteristics of these heating units are clarified below.

\section{1) Gas boiler}

The heat generation of the gas boiler $\left(H_{b}\right)$ is determined by the gas power of the gas boiler $\left(F_{b}\right)$ and the unit thermal efficiency $\left(\eta_{t h}^{b}\right)$ subject to the constraint created by the maximum heat capacity of water which is calculated with maximum water flow temperature $\left(T_{\text {flow }, b}^{\max }\right)$, water return temperature $\left(T_{\text {return }}^{t}\right)$, mass of flow water $(\dot{m})$ and the specified heat capacity of the flow water $\left(c_{p}^{\text {water }}\right)$. This is summarised in (2). Further, there will be a small amount of electricity consumption when the gas boiler is operating.

$H_{b}=\min \left\{F_{b} \eta_{\text {th }}^{b},\left(T_{\text {flow }, b}^{\max }-T_{\text {return }}^{t}\right) c_{p}^{\text {water }} \dot{m}\right\}$

2) $E H P$

For EHP, the generated heat $\left(H_{E H P}\right)$ is related to the electrical power $\left(P_{T_{\text {source }}^{E}, T_{\text {return }}^{t}}\right)$ and the coefficient of performance $\left(C O P_{T_{\text {source }}, T_{\text {return }}^{t}}\right)$. These two are correlated with the source temperature $\left(T_{\text {source }}\right)$ which could be temperature of air, ground/brine or water (for ASHP, ground source heat pump and water source heat pump respectively) and with the temperature of the return water from heating system $\left(T_{\text {return }}^{t}\right)$. An important point here is that a lower return water temperature results in a lower electrical power [14], and this "lower temperature, lower power" rule will be used to interpret the results in Section IV. In addition, the heat generation is also constrained by the maximum heat capacity of water which is consistent with other technologies introduced above. This is summarised in (3).

$$
\begin{aligned}
H_{E H P}=\min \{ & P_{T_{\text {source },}^{E} T_{\text {return }}^{t} C O P_{T_{\text {source }} T_{\text {return }}^{t}}{ }^{\prime}} \\
& \left.\left(T_{\text {flow }, E}^{\text {max }}-T_{\text {return }}^{t}\right) c_{p}^{\text {water }} \dot{m}\right\}
\end{aligned}
$$

Defrost cycles are also considered in the ASHP modelling. Defrosting will be activated when the outdoor air temperature gets lower than a specific level for a certain time [15].

\section{3) micro- $\mathrm{CHP}$}

The calculation of the element of heat generation in microCHP system $\left(H_{C H P}\right)$ is similar as the gas boiler case, while the generated electricity $\left(E_{C H P}\right)$ is related to the electrical efficiency $\left(\eta_{e}^{C}\right)$, as defined in (4).

$$
\left(\begin{array}{l}
H_{C H P} \\
E_{C H P}
\end{array}\right)=\left(\begin{array}{c}
\min \left\{F_{C} \eta_{\text {th }}^{C},\left(T_{\text {flow }, C}^{\max }-T_{\text {return }}^{t}\right) c_{p}^{\text {water }} \dot{m}\right\} \\
F_{C} \eta_{e}^{C}
\end{array}\right)
$$

Another feature of the micro-CHP modelling is start-up and shut-down processes which consume electricity without contributing useful heat, which have also been considered.

\section{Heat distribution system}

The heat distribution system links the heating units with the DHW supply and the heat emitter. (Hot) water is used as an energy carrier to transport the heat around the distribution system as required. The model also allows a supplementary buffer and a DHW tank to be considered, which could help reduce the cycling of the heating units. The schematic diagram of the heat distribution system is depicted in Fig. 1.

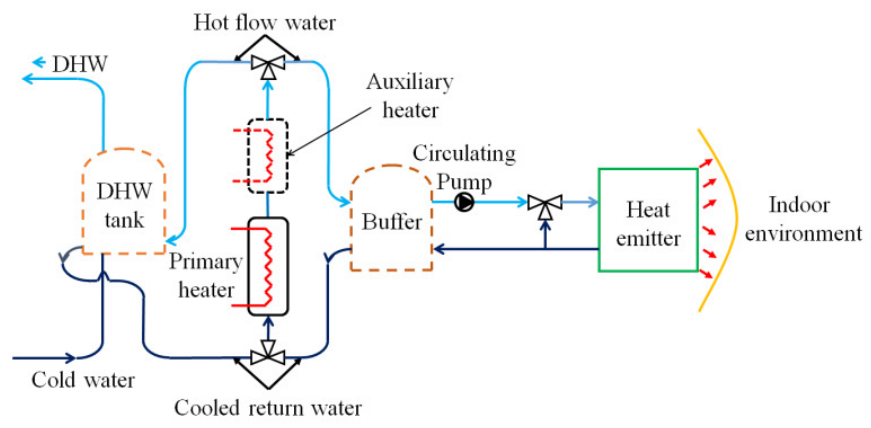

Fig. 1. Heat distribution system schematic diagram

The heat transfer through the heat distribution system $\left(H_{h s}\right)$ is determined by the flow water temperature $\left(T_{\text {flow }}^{t}\right)$, return 
water temperature $\left(T_{\text {return }}^{t}\right)$, mass of flow water $(\dot{m})$ and the heat capacity of the flow water $\left(c_{p}^{\text {water }}\right)$, as stated in $(5)$.

$$
H_{\text {hs }}=\left(T_{\text {flow }}^{t}-T_{\text {return }}^{t}\right) c_{p}^{\text {water }} \dot{m}
$$

The control of the heating unit's operation is based on the temperature signal interactions between various components. The auxiliary heater is treated as a supplementary heat supply to the primary heating unit when temperature of the buffer or the emitter (in the non-buffer case) is lower than a pre-defined set point for auxiliary heater activation.

\section{E. Space heating model}

The space heating model is composed of the building model and the heat emitter model. The building and heat emitter are mathematically represented here through an electrical analogue with the aim of analysing their thermal behaviour. Different elements are represented as different nodes and are characterised by their relevant thermal capacities and resistances.

\section{1) Building model}

Starting from the model in [13], an "upgrade" from three nodes to four nodes has been carried out, considering temperatures for indoor air and furniture $\left(x_{i}\right)$, internal wall $\left(x_{i w}\right)$, inner portion $\left(x_{e w i}\right)$, and outer portion $\left(x_{\text {ewo }}\right)$ of external wall. The reason to separate the exterior wall into two portions is because $70 \%$ houses in UK are insulated with cavity walls [16]. Furthermore, various sources of heat gain/loss, such as cooking $\left(I_{c}\right)$, metabolic $\left(I_{m}\right)$, solar radiation on interior zone $\left(I_{s i}\right)$ and external wall $\left(I_{s e}\right)$ and ventilation $\left(I_{v}\right)$, have been included. The building electrical analogue is illustrated in Fig. 2.

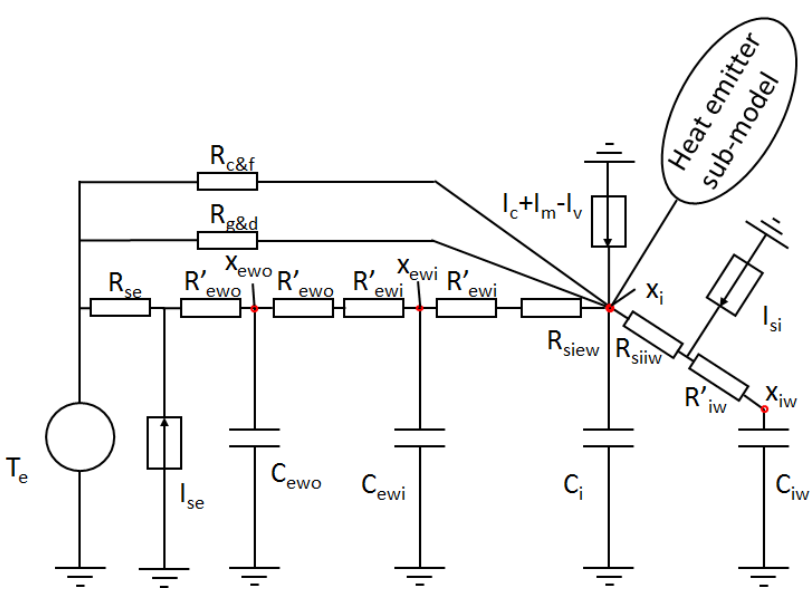

Fig. 2. Building electrical analogue

\section{2) Heat emitter model}

For heat emitters, the radiator is represented by a one-node model composed of the capacitance (determined by the heat capacity of water within it) and the resistance between the water and the indoor environment. For the under-floor heating system, because of the high thermal capacity of the floor component, one more node is added to constitute a two-node electrical analogue. The heat transfer from the heat distribution system $\left(H_{h s}\right)$ is also incorporated. The emitters' electrical analogues are shown in Fig. 3.
The state-space equations of the building with radiator and the building with under-floor heating system are represented individually in (6) and (7). [A], [B], [C] and [D] are the matrices of the state-space equations.

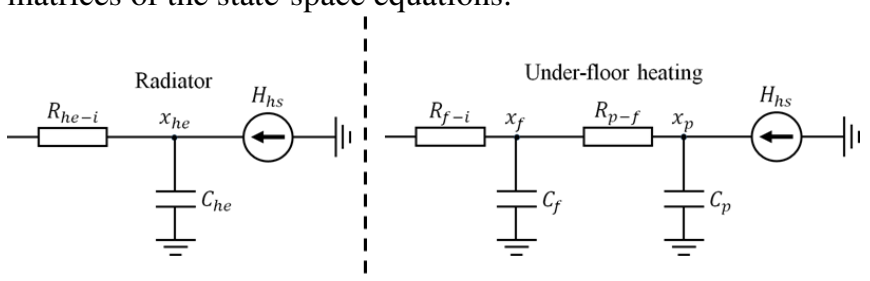

Fig. 3. Heat emitter sub-model electrical analogues

$$
\begin{aligned}
\frac{d}{d t}\left(\begin{array}{c}
x_{e w o} \\
x_{e w i} \\
x_{i} \\
x_{i w} \\
x_{h e}
\end{array}\right) & =[\mathrm{A}]\left(\begin{array}{c}
x_{e w o} \\
x_{e w i} \\
x_{i} \\
x_{i w} \\
x_{h e}
\end{array}\right)+[\mathrm{B}]\left(\begin{array}{c}
T_{e} \\
I_{s e} \\
I_{c}+I_{m}-I_{v} \\
I_{s i} \\
H_{h s}
\end{array}\right) \\
\frac{d}{d t}\left(\begin{array}{c}
x_{e w o} \\
x_{e w i} \\
x_{i} \\
x_{i w} \\
x_{p} \\
x_{f}
\end{array}\right) & =[\mathrm{C}]\left(\begin{array}{c}
x_{e w i} \\
x_{e w i} \\
x_{i w} \\
x_{p} \\
x_{f}
\end{array}\right)+[\mathrm{D}]\left(\begin{array}{c}
I_{s e} \\
I_{c}+I_{m}-I_{v} \\
I_{s i} \\
H_{h s}
\end{array}\right)
\end{aligned}
$$

The symbols for Fig. 2, Fig. 3, (6) and (7) are described below.

$T_{e} \quad$ external temperature evolution $\left({ }^{\circ} \mathrm{C}\right)$

$\mathrm{R}_{\mathrm{se}} \quad$ external surface resistance $\left({ }^{\circ} \mathrm{C} / \mathrm{kW}\right)$

$\mathrm{R}_{\text {ewo }}$ half resistance of outer portion of external wall $\left({ }^{\circ} \mathrm{C}\right.$ $/ \mathrm{kW}$ )

$\mathrm{R}_{\mathrm{c} \& \mathrm{f}} \quad$ combined resistance of ceiling and the floor $\left({ }^{\circ} \mathrm{C}\right.$ $/ \mathrm{kW})$

$\mathrm{R}_{\mathrm{g} \& \mathrm{~d}} \quad$ combined resistance of glazing and doors $\left({ }^{\circ} \mathrm{C} / \mathrm{kW}\right)$

$\mathrm{R}_{\text {ewi }}$ half resistance of inner portion of external wall $\left({ }^{\circ} \mathrm{C}\right.$ $/ \mathrm{kW}$ )

$\mathrm{R}^{\prime}$ iw half resistance of internal wall $\left({ }^{\circ} \mathrm{C} / \mathrm{kW}\right)$

$\mathrm{C}_{\text {ewo }} \quad$ capacitance of outer portion of external wall $\left(\mathrm{kJ} /{ }^{\circ} \mathrm{C}\right)$

$\mathrm{C}_{\text {ewi }} \quad$ capacitance of inner portion of external wall $\left(\mathrm{kJ} /{ }^{\circ} \mathrm{C}\right)$

$\mathrm{R}_{\text {siew }}$ resistance of external wall's internal surface $\left({ }^{\circ} \mathrm{C}\right.$ $/ \mathrm{kW}$ )

$\mathrm{R}_{\text {siiw }} \quad$ resistance of internal wall's surface $\left({ }^{\circ} \mathrm{C} / \mathrm{kW}\right)$

$\mathrm{C}_{\mathrm{i}} \quad$ capacitance inside zone of building (incl. furnishings) $\left(\mathrm{kJ} /{ }^{\circ} \mathrm{C}\right)$

$\mathrm{C}_{\mathrm{iw}} \quad$ capacitance of internal wall $\left(\mathrm{kJ} /{ }^{\circ} \mathrm{C}\right)$

$I_{s e} \quad$ solar radiation on external wall $(\mathrm{kW})$

$l_{s i} \quad$ solar radiation on interior zone (through glazed surfaces) (kW)

$I_{c} \quad$ cooking heat gain $(\mathrm{kW})$

$I_{m} \quad$ metabolic heat gain $(\mathrm{kW})$

$I_{v} \quad$ heat exchange through ventilation (with external environment) $(\mathrm{kW})$

$\mathrm{R}_{\text {he-i }} \quad$ resistance between heat emitter and indoor environment $\left({ }^{\circ} \mathrm{C} / \mathrm{kW}\right)$

$\mathrm{C}_{\mathrm{he}} \quad$ capacitance of heat emitter $\left(\mathrm{kJ} /{ }^{\circ} \mathrm{C}\right)$

$\mathrm{R}_{\mathrm{f}-\mathrm{i}} \quad$ resistance between floor and indoor environment $\left({ }^{\circ} \mathrm{C}\right.$ $/ \mathrm{kW})$

$\mathrm{C}_{\mathrm{f}} \quad$ capacitance of the floor $\left(\mathrm{kJ} /{ }^{\circ} \mathrm{C}\right)$

$\mathrm{R}_{\mathrm{p}-\mathrm{f}} \quad$ resistance between pipes and floor $\left({ }^{\circ} \mathrm{C} / \mathrm{kW}\right)$

$\mathrm{C}_{\mathrm{p}} \quad$ capacitance of under-floor pipes $\left(\mathrm{kJ} /{ }^{\circ} \mathrm{C}\right)$ 
$H_{h s} \quad$ heat transfer between heating system and emitter $(\mathrm{kW})$

$x_{\text {ewo }} \quad$ temperature of outer portion of external node $\left({ }^{\circ} \mathrm{C}\right)$

$x_{\text {ewi }} \quad$ temperature of inner portion of external node $\left({ }^{\circ} \mathrm{C}\right)$

$x_{i w} \quad$ temperature of internal wall node $\left({ }^{\circ} \mathrm{C}\right)$

$x_{i} \quad$ temperature of inside zone of the building $\left({ }^{\circ} \mathrm{C}\right)$

$x_{h e} \quad$ temperature of heat emitter $\left({ }^{\circ} \mathrm{C}\right)$

$x_{f}$ temperature of the floor $\left({ }^{\circ} \mathrm{C}\right)$

$x_{p} \quad$ temperature of under-floor pipes $\left({ }^{\circ} \mathrm{C}\right)$

To improve the accuracy and the stability of the model, the Crank-Nicolson method [17] is applied to the state space equation to substitute the Forward Euler method which has been adopted in a previous version of the model [13]. Meanwhile, the model is implemented with one-minute resolution, which helps capture all the technical features of the heating system and the temperature variation of all building components within time frames of various DR applications (which might be intra-hourly in many cases).

\section{PARAMETER SELECTION}

After introduction of the model structure and components, appropriate assignment of the parameters is considered here. In addition, the DR control and the temperature control methods applied to the heating units are detailed.

\section{A. Building and heating system parameters}

The building capacitance, initial resistance and ventilation parameters used in this paper are taken from [18]. other technical data (heating units, heat emitters and storage etc.) is retrieved from [19]-[23]. As the thermal losses of a house are mainly determined by the building resistance and ventilation values (and these parameters may be considered relatively uncertain, given the possibility of insulation improvements and draught proofing of buildings), a calibration process is employed to fit the model to real observed data. The model has been calibrated by comparing annual gas consumptions of different dwelling types (detached, semi-detached, terraced and flat with new, modern and old insulation levels), equipped with a gas boiler as the primary heating unit and radiator, with the survey data in the National Energy Efficiency Data (NEED) framework [24]. The calibration is accomplished when the discrepancy between the result and NEED data is within $5 \%$.

\section{B. Environmental parameters}

The external temperature and solar irradiance profiles are obtained from [25]. As the original profiles are at hourly resolution, the data is converted to one-minute resolution.

\section{DR control}

The DR control schemes investigated in this paper are focused on heating units (although other appliances could be used too), and the signal is considered of a "direct load control" type rather than for optional DR, as the willingness of customers to participate is out of the scope of the paper.

Two DR control strategies are considered, namely:

1. A base control strategy that is based on a timeconstrained signal which acts to turn off the heating units for a certain period following the DR signal. This type of control may be expected to be commonly required by purchasers of DR.

2. Starting from the above strategy, an additional control signal related to the comfort level of the customer is then assessed, namely, a temperature control so that when the current indoor temperature $\left(T_{i n}^{t}\right)$ is lower than the building set temperature $\left(T_{i n}^{\text {set }}\right)$ subtracting, in case, the band $\left(T_{\text {band }}\right.$ ) set by the temperature control (see Table I), the heating units could be switched back on regardless of the DR time-constrained signal. This additional control aims to emulate the likely real behaviour of domestic consumers in a DR scheme.

The flow chart demonstrating the working principle of the coordination between the two DR controls is shown in Fig. 4.

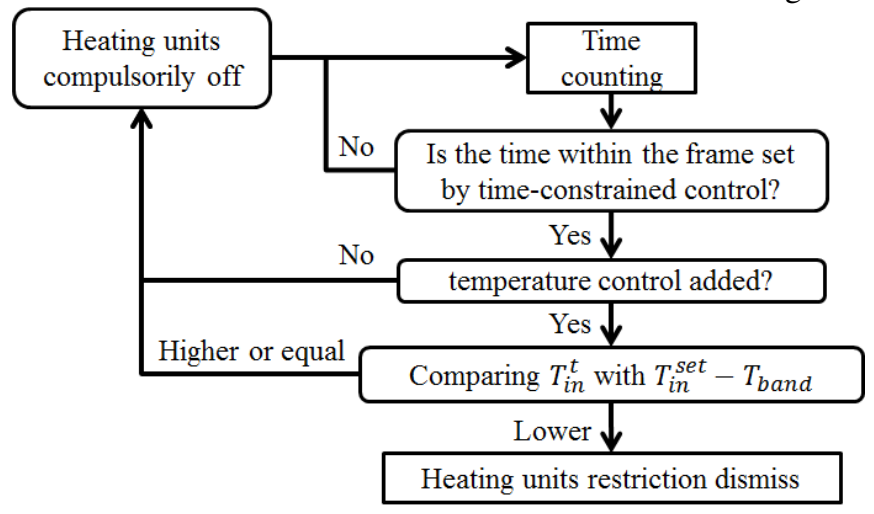

Fig. 4. Flow chart of the coordination scheme of the two DR control strategies

\section{RESULT AND DISCUSSION}

The electricity consumption/generation within a period with relatively high demand and substantial heating consumption (20:00-21:00) for DR activation is investigated for various cases on a typical winter weekday. An old detached house and a new flat are considered, that is, dwelling options with relatively large and small thermal demand, respectively. In addition, three different heater/emitter combinations, namely, ASHP with underfloor heating, ASHP with radiator, and micro-CHP with radiator, are investigated for each case. The sizes of the primary heating unit and emitter are determined by the thermal load of the house during design conditions (a very cold day). Both base and additional temperature control strategies are analysed.

Two different DR mechanisms (electricity load decrease or increase) are considered, dependant on the ETT in place. More specifically, load decrease is considered by thermal load curtailment for dwellings heated by an ASHP, producing a curtailment in electricity load. This may refer to a number of DR services, from peak shaving to reserve provision. For the micro-CHP system, an increase in the dwelling's net electricity load is considered by curtailment of the thermal load. Such action may for instance be required in response to low real-time prices, for example in the presence of an excess of wind power. Both mechanisms result in the termination of the operation of the heating units. 
TABLE I

PEAK ELECTRICAL POWER (IN KW) OF DIFFERENT CASES OF DR

\begin{tabular}{|c|c|c|c|c|c|c|c|c|}
\hline \multirow{2}{*}{$\begin{array}{l}\text { Test Ref } \\
\text { No. }\end{array}$} & \multirow{2}{*}{$\begin{array}{l}\text { Heating unit } \\
\text { control strategy }\end{array}$} & \multirow{2}{*}{$\begin{array}{c}\text { Temperature } \\
\text { control band } \\
\left({ }^{\circ} \mathrm{C}\right)\end{array}$} & \multicolumn{2}{|c|}{$\begin{array}{l}\text { ASHP with electric boiler } \\
\text { backup and radiator }\end{array}$} & \multicolumn{2}{|c|}{$\begin{array}{l}\text { ASHP with electric boiler backup } \\
\text { and underfloor heating }\end{array}$} & \multicolumn{2}{|c|}{$\begin{array}{l}\text { CHP with gas boiler backup } \\
\text { and radiator }\end{array}$} \\
\hline & & & Old detached & New flat & Old detached & New flat & Old detached & New flat \\
\hline $\mathrm{BaU}$ & Normal operation & & 8.55 & 5.10 & 8.37 & 5.82 & 1.89 & 2.92 \\
\hline 1 & Time constrained & & 10.78 & 8.07 & 10.10 & 7.49 & 3.49 & 3.49 \\
\hline 2 & & 0.5 & 8.73 & 8.07 & 10.10 & 7.49 & 3.49 & 3.49 \\
\hline 3 & & 1 & 9.89 & 8.07 & 10.10 & 7.49 & 3.49 & 3.49 \\
\hline
\end{tabular}

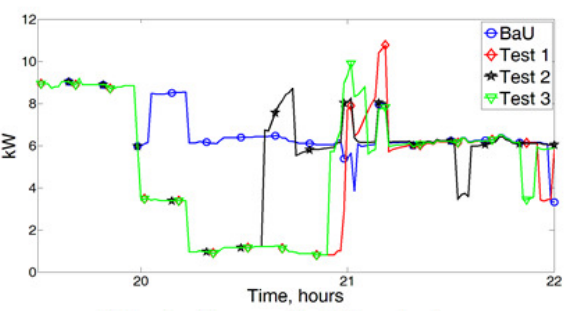

old detached house with ASHP and radiator

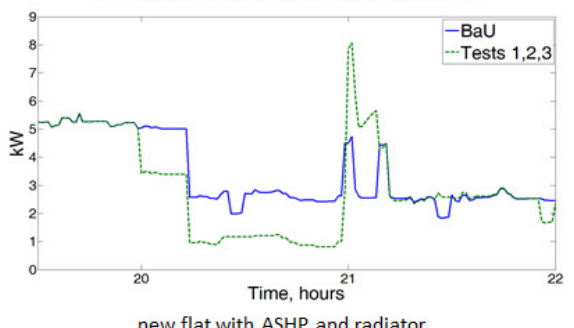

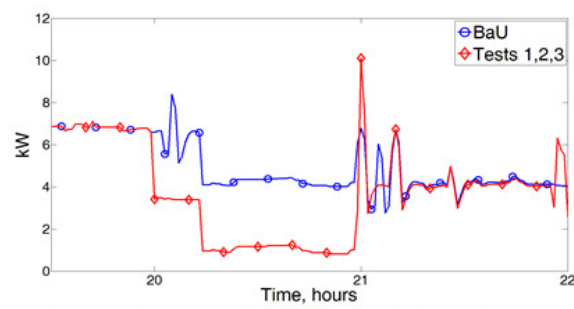

old detached house with ASHP and underfloor heating

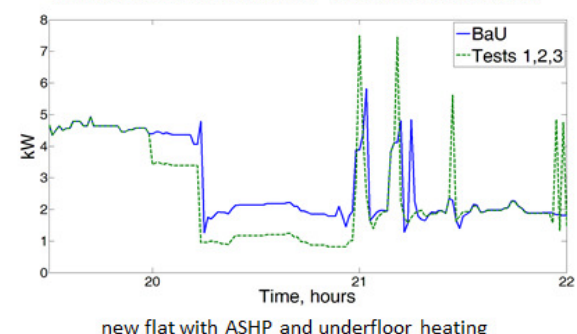

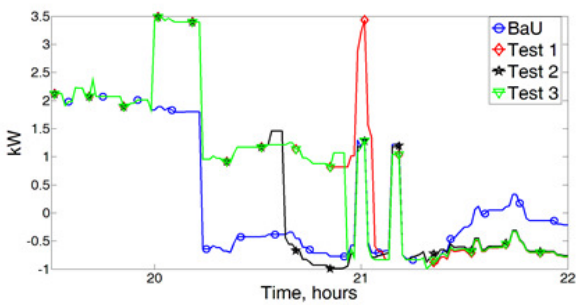

old detached house with micro-CHP and radiator

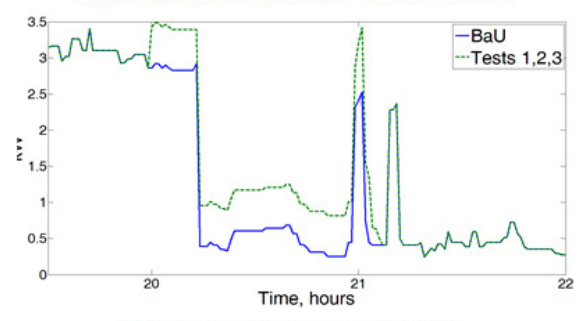

new flat with micro-CHP and radiator

Fig. 5. Electricity consumption around the DR period (20:00-21:00) for an old detached house (top) and a new flat (bottom) for different ETT

A summary of the peak power of all tests in different cases and the detail of their control strategies are shown in Table I, with the business as usual (BaU) test meaning no DR is applied. The graphs of the electricity consumption (and generation, in the case of negative consumption) around the DR period of all cases are displayed in Fig. 5 for an old detached house (top) and a new flat (bottom).

\section{A. ASHP}

The left hand side and central graphs of Fig. 5 represent the electricity consumption of houses equipped with ASHP. There are clear differences in peak powers of the different cases. For example, in the $\mathrm{BaU}$ test, the peak power of the old detached house with radiator case is $68 \%$ higher than the case of new flat with radiator. Additionally, considering underfloor heating cases the old detached house's peak is $44 \%$ higher than the new flat in the BaU test. This is primarily due to the larger size of the primary heating unit in the old detached house, as the power rating is related to the thermal load of the house, and the old detached house has much higher thermal losses than the new flat.

1) Time control only

It can be clearly seen in Table I that the peak power of Test \#1 is higher than in BaU, mostly due to the "payback" effect of the heating system trying to re-establish the set temperature though a coordinated action of both the primary heating unit and the auxiliary heater. Depending on the case, the difference between $\mathrm{BaU}$ and Test \#1 is in the order of $2-3 \mathrm{~kW}$. This value is due to the compound effect of two factors:
- The power rating of the auxiliary heater, which is automatically activated at the end of the DR window to regain the lost thermal comfort quickly, is set to be $3 \mathrm{~kW}$.

- After the DR period, the temperature of the heating system is lower compared to BaU test. Therefore, due to the "lower temperature, lower power" rule, the input power of the ASHP is smaller than before the DR signal.

\section{2) Temperature control}

In the case of the old detached house with radiator, the temperature control method manages to decrease the peak power around the DR. For example, the peak power with 0.5 ${ }^{\circ} \mathrm{C}$ temperature control (Test \#2) case is comparable to the $\mathrm{BaU}$ test $(8.73$ vs $8.55 \mathrm{~kW})$. There is also about $1 \mathrm{~kW}$ reduction with $1 \mathrm{C}^{\circ}$ temperature control (Test \#3), compared to the only time control (Test \#1). This is due to temperature control method preventing the temperature of the heating system dropping too low which avoids the activation of the auxiliary heater. However, although the addition of the temperature control method serves to guarantee a level of thermal comfort for the dwelling occupant and also restricts the payback effect, the effectiveness of the DR control is compromised. This is because the heating units could start up earlier than the time frame set by the DR control. This is illustrated in the temperature control tests in old detached house, ASHP, radiator case in Fig. 5, where the heating units start up at 20:36 and 20:55 respectively, which is earlier than 21:00 set by the DR time-constrained control.

On the other hand, the load shapes of the other ASHP cases (old detached house with radiator, and both dwelling types 
with underfloor heating) show that the implementation of the temperature control doesn't have any effect with respect to the time constrained case. In fact, the indoor temperatures of the low thermal loss house (such as the new flat) and the houses with high thermal inertia emitter (such as underfloor heating) drop relatively slowly, and thus will not hit the threshold set by the temperature controls within the one-hour DR period.

\section{B. Micro-CHP}

The top and bottom graphs in the right hand side of Fig. 5 represent the electricity consumption/generation of houses with a micro-CHP unit.

\section{1) Time control only}

The electricity consumptions of the micro-CHP cases increase remarkably in the DR control tests compared with $\mathrm{BaU}$ test. In fact, it can be seen from Fig. 5 that after DR the electrical loads are higher by $1.6 \mathrm{~kW}$ and $0.57 \mathrm{~kW}$ in the detached and flat house types, respectively; these values are exactly the electrical power ratings of the micro-CHP system of two house types. At the same time, after the DR interval, the electricity generation exceeds the $\mathrm{BaU}$ generation in the old detached house case (bringing reduced net electricity load). This is due to the CHP unit operating longer to compensate the relatively larger amount of heat loss during the DR period.

\section{2) Temperature control}

When applying temperature controls, the results from the micro-CHP cases are similar to the ASHP cases. Again the micro-CHP restarts earlier than the end time set by the DR control in the old detached house case. This is because the thermal loss of the house is not related to the choice of heating units, or choice of heat emitter (assuming heat emitters are specified to the same standards). Meanwhile, there is a small power increase (about $0.25 \mathrm{~kW}$ ) before the micro-CHP restarts operation and thus electricity generation in the DR control tests of the old detached house. This is illustrated by the increment of Test \#1 at around 21:36 and the discrepancy between Test \#2 and \#3 at around 21:50. This value is composed of electricity consumption of the micro-CHP, during the start-up process, and of the gas boiler, whose operation is triggered (for quick regain of thermal comfort).

\section{CONCLUSION}

In this paper, a high resolution domestic energy consumption model has been applied to investigate the load shapes of dwellings which installed different ETT. Furthermore, the impacts of different DR strategies have been presented. The computation time of the model for the analysis of a single house and single day case is 2 seconds on a computer with $3.4 \mathrm{GHz}$ CPU. The results quantify the load shape changes and payback effects due to the application of the DR control and the effect on DR effectiveness of consideration of the occupants' comfort level in terms of DR duration. Effects such as the increase in dwelling peak electricity demand, which may, if replicated across many dwellings and not mitigated by aggregation and control of such dwellings, become problematic for a distribution network operator can be discerned. Hence, based on physical models of the heating system/heat emitter/building fabric, this work has aimed at bringing insights into the implications of adopting different DR control strategies in different dwellings with different ETT and thermal inertia characteristics. Future works aim at exploring further load shape changes at an aggregated level and establishing coordination control methods on the heating units of single houses and among different houses to alleviate negative individual and aggregated effects.

\section{REFERENCES}

[1] UK Government, Climate Change Act 2008. UK Government, 2008.

[2] DECC and V. Thompson, "Estimates of heat use in the United Kingdom in 2012," 2013.

[3] National Grid, "UK Future Energy Scenarios," 2012.

[4] B. Ummels, E. Pelgrum, and W. Kling, "Integration of large-scale wind power and use of energy storage in the netherlands' electricity supply," IET Renew. Power Gener., no. December 2007, 2008.

[5] A. Navarro-Espinosa and P. Mancarella, "Probabilistic modeling and assessment of the impact of electric heat pumps on low voltage distribution networks," Appl. Energy.

[6] F. Oldewurtel, T. Borsche, M. Bucher, P. Fortenbacher, M. Gonzalez Vaya, T. Haring, J. L. Mathieu, O. Megel, E. Vrettos, and G. Andersson, "A framework for and assessment of demand response and energy storage in power systems," in 2013 IREP Symposium Bulk Power System Dynamics and Control - IX Optimization, Security and Control of the Emerging Power Grid, 2013, pp. 1-24.

[7] C. Kolokathis, "a step towards the future of electricity networks'," 2009.

[8] A. Berard, N. Veillerobe, M. Hennebel, and Y. Phulpin, "Strategies for demand load control to reduce balancing costs," in 2010 7th International Conference on the European Energy Market, 2010, pp. 16.

[9] H. Salehfar and A. D. Patton, "Modeling and evaluation of the system reliability effects of direct load control," IEEE Trans. Power Syst., vol. 4, no. 3, pp. 1024-1030, 1989.

[10] S. K. Firth, K. J. Lomas, and a. J. Wright, "Targeting household energyefficiency measures using sensitivity analysis," Build. Res. Inf., vol. 38, no. 1, pp. 25-41, Feb. 2010.

[11] S. Natarajan and G. J. Levermore, "Predicting future UK housing stock and carbon emissions," Energy Policy, vol. 35, no. 11, pp. 5719-5727, Nov. 2007.

[12] I. Richardson, M. Thomson, D. Infield, and C. Clifford, "Domestic electricity use: A high-resolution energy demand model," Energy Build., vol. 42, no. 10, pp. 1878-1887, Oct. 2010.

[13] N. Good, L. Zhang, A. Navarro-Espinosa, and P. Mancarella, "Physical modeling of electro-thermal domestic heating systems with quantification of economic and environmental costs," in Eurocon 2013, 2013, no. July, pp. 1164-1171.

[14] Calorex, "Domestic Heat Pumps," 2010.

[15] P. Dunbabin, H. Charlick, and R. Green, "Detailed analysis from the second phase of the Energy Saving Trust's heat pump field trial," 2013.

[16] Department of Energy and Climate Change, "Estimates of Home Insulation Levels in Great Britain."

[17] J. Crank and P. Nicolson, "A practical method for numerical evaluation of solutions of partial differential equations of the heat-conduction type," Adv. Comput. Math., vol. 6, no. 1, pp. 207-226, Dec. 1996.

[18] E. Curioni, "Mphil thesis: Uk domestic heat demand modeling," The University of Manchester, 2013.

[19] Myson Corporation, "Myson Panel Radiator Technical Guide.” 2010.

[20] Creda Heating, "Intelligent heating technology Range \& Specification." 2012.

[21] Microtherm, "Standard Block High Temperature Microporous insulation." 2008.

[22] CIBSE, Underfloor heating: Design \& Installation Guide, 2nd ed. Chartered Institution of Building Services Engineers, 2012.

[23] CIBSE, Domestic Heating - Design Guide, 8th ed. Chartered Institution of Building Services Engineers, 2010.

[24] DECC, "National Energy Efficiency Data- Framework," 2013.

[25] CIBSE, Guide A: Environmental design, 7th ed. Chartered Institution of Building Services Engineers, 2006. 